\title{
ACCLIMATIZATION AND LEAF ANATOMY OF MICROPROPAGATED FIG PLANTLETS ${ }^{1}$
}

\author{
CHRYSTIANE FRÁGUAS CHIRINÉA ${ }^{2}$, MOACIR PASQUAL ${ }^{3}$, \\ APARECIDA GOMES DE ARAUJO ${ }^{4}$, ALBA REGINA PEREIRA ${ }^{5}$, EVARISTO MAURO DE CASTRO
}

ABSTRACT - The survival of micropropagated plants during and after acclimatization is a limiting process to plant establishment. There is little information on how the anatomy of vegetative organs of Ficus carica can be affected by culture conditions and acclimatization. The present research aimed to study the effects of time on culture medium and substrates during the acclimatization of fig tree plantlets produced in vitro, characterizing some leaf anatomy aspects of plantlets cultured in vitro and of fig trees produced in field. Plantlets previously multiplied in vitro were separated and transferred into Wood Plant Medium (WPM) where they were kept for 0, 15, 30, 45 and 60 days. Different substrates were tested and studies on leaf anatomy were performed in order to compare among plantlets grown in vitro, plantlets under 20,40 and 60 days of acclimatization, and field grown plants. Keeping plantlets for 30 days in WPM allowed better development in Plantmax during acclimatization. Field grown plants presented higher number of stomata, greater epicuticular wax thickness and greater leaf tissue production compared to in vitro ones. The leaf tissues of in vitro plantlets show little differentiation and have great stomata number compared with acclimatized plants, which reduce the number of stomata during the acclimatization process.

Index terms: Ficus carica L., substrate, stomata, parenchyma.

\section{ACLIMATIZAÇÃO E ANATOMIA FOLIAR DE PLÂNTULAS DE FIGO MICROPROPAGADAS}

RESUMO: A sobrevivência de plantas micropropagadas durante e após a aclimatização é um processo limitante para o estabelecimento de plantas. Poucas informações são encontradas de como a anatomia de órgãos vegetativos de Ficus carica pode ser afetada pelas condições de cultivo e aclimatização. O presente trabalho teve por objetivo estudar os efeitos do tempo em meio de cultura e substratos durante a aclimatização de plântulas de figueira produzidas in vitro e cultivadas no campo. Plântulas multiplicadas in vitro foram separadas e transferidas para meio WPM, onde foram mantidas por $0 ; 15 ; 30 ; 45$ e 60 dias. Diferentes substratos foram testados, e os estudos de anatomia foliar foram executados a fim de comparar plântulas crescidas in vitro, plântulas com 20; 40 e 60 dias de aclimatização e plantas crescidas a campo. Plântulas mantidas por 30 dias em WPM apresentaram melhor desenvolvimento em Plantmax durante a aclimatização. Plantas de campo apresentam elevado número de estômatos, maior espessura de cera epicuticular e do tecido foliar em comparação com plantas cultivadas in vitro. Já plântulas crescidas in vitro mostram tecidos foliares pouco desenvolvidos e maior número de estômatos em comparação com plantas aclimatizadas, que reduzem o número de estômatos ao longo do processo de aclimatização.

Termos para Indexação: Ficus carica L., substrato, estômato, parênquima.

\footnotetext{
${ }^{1}$ Trabalho (253-11). Recebido em: 07-11-2011. Aceito para publicação em: 16-10-2012.

${ }^{2}$ D.Sc., Atelier de Paisagismo e Arte Floral, Botucatu, SP, Brasil. E-mails: chrysbf@gmail.com

${ }^{3}$ D.Sc., Professor, Universidade Federal de Lavras (UFLA), Lavras-MG, Brasil. E-mails: mpasqual@dag.ufla.br, emcastro@dbi.ufla.br ${ }^{4}$ D.Sc., Pesquisadora EMDAGRO, Aracaju-SE, Brasil. E-mail: agaraujo2003@hotmail.com

${ }^{5}$ D.Sc., CEFET/RJ Campus de Valença (Centro Federal de Educação Tecnológica Celso Suckow da Fonseca) Valença-RJ, Brasil. E-mail: albaenbt@gmail.com
} 


\section{INTRODUCTION}

Both greenhouse and field environments have lower relative humidity, high light intensity, and septic conditions that are stressful to the micropropagated plants compared to in vitro conditions. Most species grown in vitro, including the fig tree, require an acclimatization process before transferring them to the greenhouse as well as to the field. This practice ensures the high survival rate and vigorous growth of in vitro plantlets when transferred to soil. Researchers are successful in improving the survival index of in vitro fig plantlets during acclimatization. A 90-95\% survival rate was obtained for fig plantlets (POSPÍŠILOVÁ et al., 1999; HAZARIKA, 2003).

Despite of its importance, micropropagation under heterotrophic conditions is responsible for the induction of plants physiological and structural modifications, considered as different from that obtained in ex vitro plants (YOKOTA et al., 2007), such as low regulation mechanism of water loss, mainly due to inefficient stomata functionality and the formation of epicuticular wax and reduced development of photosynthetic tissues (LAMHANEDI et al., 2003). The present research aimed to study the effects of time on culture medium and substrates during the acclimatization of fig tree plantlets produced in vitro, characterizing some leaf anatomy aspects of plantlets cultured in vitro and of fig trees produced in field.

\section{MATERIALS AND METHODS}

Young shoots (30-60 mm) of Ficus carica cv. 'Roxo de Valinhos' were collected from mature plants during the spring, washed with $0.1 \%(\mathrm{v} / \mathrm{v})$ detergent solution, rinsed with water, surface-sterilized with $70 \%(\mathrm{v} / \mathrm{v})$ ethanol for $10 \mathrm{~s}$, and rinsed with sterile distilled water. The shoots were sterilized with $\mathrm{NaClO} 1 \%(\mathrm{v} / \mathrm{v})$ for $15 \mathrm{~min}$ and rinsed three times with sterile distilled water. After the process of the sterilization, stem apex (apical meristem and two a three leaf primordia) were excised and used as the initial sources of explants, in order to obtain sufficient clone explants to develop acclimatization experiments. A preliminary multiplication step was carried out by placing primary shoot explants individually into test tubes holding $15 \mathrm{~mL}$ of MS (MURASHIGE; SKOOG, 1962) medium containing $3 \%$ sucrose, $0.7 \%$ agar, $2.22 \mu \mathrm{M}$ 6-benzylaminopurine (BAP), $0.29 \mu \mathrm{M}$ gibberellic acid (GA) and 0.05 $\mu \mathrm{M}$ naphthalene-acetic acid (NAA). Cultures were maintained inside growth chamber at $27 \pm 2^{\circ} \mathrm{C}$, under 16-hour photoperiod with $35 \mu \mathrm{mol} \mathrm{m}^{-2} \mathrm{~s}^{-1}$ light intensity. After each period of two months, shoot clumps growing from the explants were separated and these new explants were subcultured individually in fresh medium for another multiplication cycle, until five cycles had been completed.

The plantlets obtained were used in two separate experiments: one to study time in culture medium and different substrates during the acclimatization of fig tree plantlets produced in vitro, and the other to evaluate leaf anatomy aspects of plantlets cultured in vitro and of fig trees produced in field conditions.

\section{Time in culture medium and different substrates for acclimatization}

The plantlets were subjected to 25 treatments: five periods in Wood Plant Medium (WPM) lacking plant growth regulators (PGR-free) followed by acclimatization in five different substrates. Afterwards, individual plantlets were transferred from multiplication media of PGR-free WPM and kept there for 0 , $15,30,45$ and 60 days. Plantlets corresponding to 0 days in PGR-free WPM were kept in open tubes for five days inside growth chamber, and transferred directly from multiplication medium into different substrates. After different periods in PGR-free WPM, and before removing plantlets, all tubes were kept open for five days inside growth chamber in order to promote gradual acclimatization. Plantlets kept during $0,15,30,45$ and 60 days in PGR-free WPM showed shoot length of about 1.0, 1.5, 2.0, 4.5 and 7.0 $\mathrm{cm}$ respectively, and only 0 and 15 -day cultured ones did not develop roots. The plantlets were transferred to plastic trays ( 25 cells of $150 \mathrm{~cm}^{3}$ ) containing five different substrates: horticultural substrate Plantmax; Plantmax + Vermiculite $(1: 1 \mathrm{v} / \mathrm{v})$; Plantmax + Humus $(1: 1 \mathrm{v} / \mathrm{v})$; Humus + Vermiculite $(1: 1 \mathrm{v} / \mathrm{v})$; Plantmax + Humus + Vermiculite $(1: 1: 1 \mathrm{v} / \mathrm{v})$.

Plants were maintained in a greenhouse (intermittent misting and 50\% shading for the first month), when percentages of survival and plant heights (measured from the substrate level up to the top of the apical meristem) were determined after 80 days of cultivation.

These treatments were arranged under a completely randomized design, with four replications, each replication consisting of five cells of the tray containing one plantlet. However, as plantlets corresponding to 0 days in WPM medium did not survive acclimatization, data were analyzed as a $4 \times 5$ factorial scheme (20 treatments). Data were submitted one-way Anova, $\mathrm{F}$ test (1\% of probability) and the means were compared by the Scott-Knott's test, using the SISVAR software. 


\section{Leaf anatomy}

For the second experiment - for the anatomical study of leaves - in vitro plantlets (maintained for 45 days in PGR-free WPM inside growth chamber), plants under 20, 40 and 60 days of acclimatization Plantmax and greenhouse (with intermittent misting and 50\% shading in the first month), and adult plants cultivated in the field (natural conditions) were compared.

Different substrates were tested and anatomical leaf studies were carried out to compare between naturally grown plants and in vitro developed plantlets after 20, 40 and 60 days of acclimatization.

The first completely expanded leaf from the shoot tips were fixed in $70^{\circ} \mathrm{GL}$ ethanol. The anatomical study was based on the light microscopic exam of freehand sections, by using a stainless-steel blade. Sections of $25 \mu \mathrm{m}$ extracted from the medium part of the leaves were bleached using $\mathrm{NaClO}$ (solution containing $0.5 \%$ of active chlorine), for a period that varied between three and five minutes, washed afterwards in distilled water, neutralized in acetic acid $1 \%$ and prepared in glycerin $50 \%$ with coloration.

For the studies of epidermical faces thickness, as well as palisade and spongy parenchyma, transversal sections were performed, and stained with astra blau-safranin (astrablau 1\% and safranin 0.1\% at the proportion of 7:3). Sections were placed in light microscopy slides with water glycerin solution (at the proportion of $0.5: 0.5$ ). The thickness of leaves was measured by using the microscope micrometric scale (four measurements in each plant, in a total of 5 plants) and means were calculated.

The stomata density (number of stomata per square millimeter of leaf area), and the average of polar (length) and equatorial (width) stomata size from the median region of the abaxial leaf surface were determined by freehand paradermal sections with stainless steel blades, with about $25 \mu \mathrm{m}$ sections, placed on slides and covered with $1 \%$ safranin and glycerin-water solution (at the proportion of 0.5:0.5). Three regions were measured in the median leaf blade, summarizing a total of 30 observations per treatment.

The measurements were made with an Olympus $\mathrm{CBB}^{\circledR}$ light microscope (Olympus Co, Tokyo, Japan), according to the technique described by Labouriau et al. (1961). Photomicrographs were obtained by using an Olympus BX $60{ }^{\circledR}$ light microscope.

The experimental design consisted of five treatments (in vitro, 20, 40 and 60 days of acclimatization, and plants in the field) with five replications (consisting of five individual plants per replication) analyzed as a completely randomized assay. Data were submitted one-way Anova, F test (1\% of probability) and the means were compared by the ScottKnott's test, using the SISVAR software.

\section{RESULTS AND DISCUSSION}

\section{Time in culture medium and different substrates for acclimatization}

According to the analysis of variance there was significant interaction between time in culture medium and different substrates for acclimatization. Plantlets transferred immediately from culture medium (0 days in PGR-free WPM) to acclimatization under greenhouse conditions did not survive in any substrate. Plantlets kept for 15, 30, 45 and 60 days in PGR-free WPM showed better survival rates in Plantmax and Plantmax + Vermiculite, compared to other substrates (Table 1).

Similar observations were reported by Pereira and Fortes (2001), with positive results for treatments with rooting periods in apple trees, with an average of $90 \%$ survival rate for treatments maintained during 12, 15, 21 and 30 days under in vitro conditions.

Plantlets kept for 15 days in culture medium showed survival rates of around 95\% in Plantmax + Vermiculite substrate, while Plantmax alone resulted in $85 \%$ of survival. The highest survival rates for plantlets kept for 30, 45 and 60 days were observed in Plantmax (90, 95 and 95\%, respectively), and Plantmax + Vermiculite. The best results obtained with Plantmax are due, probably, to the fact that this substrate contains the appropriate amount of nutrients for the initial period of development of plantlets. Fifty percent shading during the first month probably also favored the survival of plantlets, reducing light stress. In order to avoid it, the control of the luminous intensity through partial shading is important, reducing brightness into a point between $50 \%$ and $90 \%$, providing similar or slightly superior atmosphere to the one found in the growth chamber.

Plantlets cultured for 60 days before transference to Plantmax + Humus and Plantmax had the highest growth rates $(8.9$ and $8.6 \mathrm{~cm}$, Table 1). Although the presence of humus reduced the survival of 60-day cultured plantlets, the remaining ones developed better, probably due to higher nutrient availability. The substrates Plantmax + Vermiculite, Plantmax + Humus + Vermiculite and Humus + Vermiculite induced similar plantlet heights, corresponding to $6.77,6.87$ and $6.97 \mathrm{~cm}$, respectively. For plantlets cultured for 15, 30 and 45 days, Plantmax alone, allowed the highest growth $(5.75 ; 7.85$ and 


\section{$7.8 \mathrm{~cm}$, respectively).}

Other authors achieved satisfactory results by acclimatizing rooted plantlets of Ficus carica. Demiralay et al. (1998) observed a survival rate of 90\% for Ficus carica 'Bursa Siyahi' using turf and perlite (2:1 v/v) as substrate. Kumar et al. (1998) describes success in the acclimatization of the cultivar 'Gular' using initially an artificial sterile substrate for approximately one month. Subsequently these plants were transferred to soil and kept for two more weeks before transplantation to field environment.

Plantmax alone presented good results, although some others do not show significant difference when compared to this treatment. However, the easy acquisition and the cost reduction are considerable factors for the choice of Plantmax as substrate for fig plants acclimatization.

\section{Leaf anatomy}

There are several anatomical differences reported for plantlets grown in different environments (REZENDE et al., 2008; DOUSSEAU et al., 2008). The thickness of the epidermical faces varies according to the treatments (Table 2). The size of leaf tissues amounts and polar and equatorial diameters of stomata were influenced by different treatments (Tables 2 and 3).

Until 20 days after acclimatization there was no statistical difference observed for the adaxial surface epidermis. After 40 days of acclimatization an increase of $4.5 \mu \mathrm{m}$ in thickness was observed and it did not differ from plants after 60 days with $6.2 \mu \mathrm{m}$, but the field plants increased the thickness adaxial surface epidermis $(18.1 \mu \mathrm{m})$ compared on in vitro plants.

The abaxial surface epidermis was thinner in in vitro plantlets and did not significantly differ from plantlets at 20 and 40 days of acclimatization, but at 60 days the thickness was close to that observed in adult plants under field conditions (Table 2). The excessive loss of water, which contributed to plant desiccation after transference to greenhouse, has been attributed to many characteristics induced by the environmental in vitro conditions. It may be mentioned that the retarded cuticle development, epicuticular waxes deposition and functional stomata apparatus during in vitro culture causes excessive transpiration rates in leaves of plantlets taken out of the culture vessels (POSPÍŠILOVÁ et al., 1999; LAMHANEDI et al., 2003). Figure $1 \mathrm{D}$ shows that after 60 days the leaves formed ex vitro present a transitory anatomy with thicker cuticles. This increase in thickness, observed along acclimatization, is useful in avoiding the excessive loss of water, which avoids desiccation of plantlets when transferred to a field environment (CASSON; GRAY, 2008).

Non-glandular and glandular trichomes were present all over the epidermis in all treatments (data not presented). Field established plants had thicker epidermical faces, probably due to their exposure to the weather conditions, especially the higher light intensity. This feature can be useful for reflecting excessive radiation and reducing water loss (SOUZA et al., 2010). Leaf lamina thickness was also higher in field grown plants (Table 2). By the studies of the epidermis abaxial face (Figure 2) it can be observed that for in vitro culture, and at 20, 40 and 60 days of acclimatization, cells have more intense sinuous walls than cells of field grown plants.

There was variation in density and size of stomata according to the different treatments (Table 3). A higher stomata density was found in field grown plants (Table 3). Nevertheless, when comparing in vitro plants, with plants under acclimatization $(20,40$ and 60 days), in vitro plants presented greater stomata density, which is due to the environment conditions observed in the culture chambers and the higher in vitro humidity. There was a decrease in the stomata density during acclimatization (Figures $2 \mathrm{~B}, \mathrm{C}, \mathrm{D}$ and Table 3 ), and these results agree with those observed by Barry-Etienne et al. (2002) and are also concluded in the review by Pospíšilová et al. (1999). Increasing the ex vitro acclimatization period from 0 to 60 days, morphological alterations occurred in these cells evidenced by the varying relation of length/width of the stomata, ranging from 1.25 to 1.65 . These observations demonstrate that the lower the relation, the less functional are the stomata cells (PESCHEL et al., 2003), and the opposite is also true, as plants totally acclimatized present the highest relation and as all the stomata diameter modifications measurements were conduced only in opened stomata.

Variations in the stomata densities depend on the species and the cultivation condition. In a number of species both light intensity and $\mathrm{CO}_{2}$ concentrations have proved to influence the frequency at which stomata develop on leaves (CASSON; GRAY, 2008; YOKOTA et al., 2007). The leaves formed in vitro showed round stomata, which were not observed in acclimatized plants (Figure 2).

Data of Table 3 indicate that the greatest polar dimension was found in leaves of plants grown in the field. For equatorial size, only plants with 60 days of acclimatization differed from the other treatments, showing the lowest average means.

Plantlets in vitro showed little differentiation in the leaf mesophyll and high proportion of intercellular spaces when compared to other plants (Table 
2 and Figure 1A). Only field grown plants had two layers of palisade parenchyma (Figure 1E). In acclimatized plants, this tissue is more developed than in plantlets in vitro. In plants acclimatized during 60 days, the second layer is starting to be formed (Figures 1D).

The thickness of the spongy parenchyma in leaves of acclimatized plants showed an increase, but at 20 and 40 days no statistical difference was found (Table 2 and Figure 1), indicating that plantlets need a period greater than 40 days to be acclimatized. Field cultivated plants showed greater thickness of spongy parenchyma, which also differed from the other treatments because of their compacted cells (Figure 1E). Similar tendency was observed by Barry-Etienne et al. (2002) for coffee, whose data on histological observations showed that the leaves of plantlets obtained from somatic embryos produced in vitro or ex vitro were not as thick as seedling leaves as their spongy parenchyma was less well-developed. The increase in the width of the parenchyma is due to higher irradiance, which was also observed by Hanba et al. (2002) in in vitro Acer species.
From the results shown, it can be concluded that plantlets cultured during 30 days in WPM medium lacking growth regulators have good development in the Plantmax substrate during acclimatization. Field grown plants presented higher number of stomata, greater epicuticular thickness and greater leaf tissue production compared to in vitro ones. In vitro plantlets ( 0 days of acclimatization) have low differentiated leaf tissues and great number of stomata compared acclimatized plants. During acclimatization, new leaves produced ex vitro had a transition anatomy compared to that observed in vitro and in field plants. Thus it can be clearly inferred that also for fig plants (Ficus carica), the abnormalities in morphology, anatomy, and probably physiology of plantlets cultivated in vitro can be repaired by the use of appropriated period and condition of acclimatization.

TABLE 1- Height (cm) and survive (\%) of plantlets cultured for distinct periods of time (days) in WPM culture medium lacking growth regulators and cultivated in different substrata under greenhouse conditions.

\begin{tabular}{cccccc}
\hline \multirow{2}{*}{ Days on WPM medium } & \multicolumn{5}{c}{ Plantlet height $(\mathrm{cm})$} \\
\cline { 2 - 6 } & $\mathrm{P}$ & $\mathrm{P}+\mathrm{V}$ & $\mathrm{P}+\mathrm{H}$ & $\mathrm{P}+\mathrm{H}+\mathrm{V}$ & $\mathrm{H}+\mathrm{V}$ \\
\hline 15 & $5.75 \mathrm{~A}$ & $3.35 \mathrm{~B}$ & $2.74 \mathrm{~B}$ & $3.17 \mathrm{~B}$ & $3.65 \mathrm{~B}$ \\
30 & $7.85 \mathrm{~A}$ & $3.62 \mathrm{C}$ & $3.87 \mathrm{C}$ & $3.57 \mathrm{C}$ & $4.55 \mathrm{~B}$ \\
45 & $7.80 \mathrm{~A}$ & $5.72 \mathrm{C}$ & $5.7 \mathrm{C}$ & $5.65 \mathrm{C}$ & $6.42 \mathrm{~B}$ \\
60 & $8.60 \mathrm{~A}$ & $6.77 \mathrm{~B}$ & $8.92 \mathrm{~A}$ & $6.87 \mathrm{~B}$ & $6.97 \mathrm{~B}$ \\
mean & 7.50 & 4.86 & 5.31 & 4.81 & 5.40 \\
\hline \multirow{2}{*}{ Days on WPM medium } & & \multicolumn{5}{c}{ Survive $(\%)$} \\
\cline { 2 - 6 } & $\mathrm{P}$ & $\mathrm{P}+\mathrm{V}$ & $\mathrm{P}+\mathrm{H}$ & $\mathrm{P}+\mathrm{H}+\mathrm{V}$ & $\mathrm{H}+\mathrm{V}$ \\
\hline 15 & $85 \mathrm{~A}$ & $95 \mathrm{~A}$ & $55 \mathrm{C}$ & $25 \mathrm{D}$ & $70 \mathrm{~B}$ \\
30 & $90 \mathrm{~A}$ & $85 \mathrm{~A}$ & $55 \mathrm{~B}$ & $30 \mathrm{C}$ & $80 \mathrm{~A}$ \\
45 & $95 \mathrm{~A}$ & $95 \mathrm{~A}$ & $25 \mathrm{~B}$ & $40 \mathrm{~B}$ & $30 \mathrm{~B}$ \\
60 & $95 \mathrm{~A}$ & $85 \mathrm{~A}$ & $30 \mathrm{~B}$ & $35 \mathrm{~B}$ & $35 \mathrm{~B}$ \\
Mean & 91.25 & 90.0 & 41.25 & 32.5 & 53.75 \\
\hline
\end{tabular}

Means followed by the same letter horizontally do not differ by the Scott-Knott test at $5 \%$ of probability.

$\mathrm{P}=$ Plantmax $\mathrm{P}+\mathrm{V}=$ Plantmax + Vermiculite $\mathrm{P}+\mathrm{H}=$ Plantmax + Humus; $\mathrm{P}+\mathrm{H}+\mathrm{V}=$ Plantmax + Humus + Vermiculite; $\mathrm{H}+\mathrm{V}=\mathrm{Humus}+$ Vermiculite. 
A

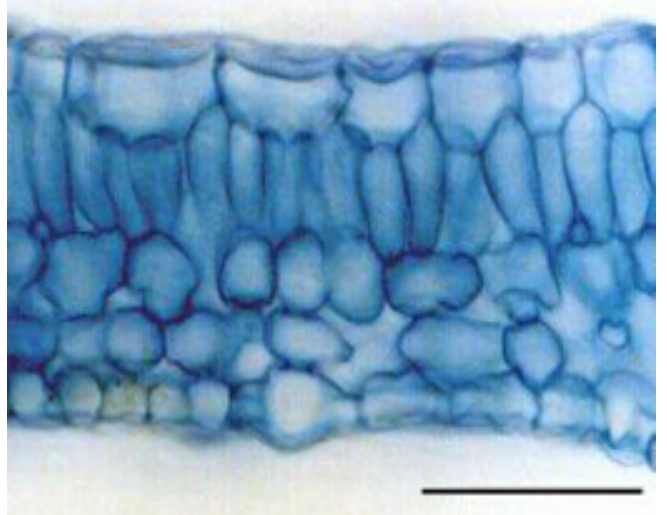

$\mathrm{C}$

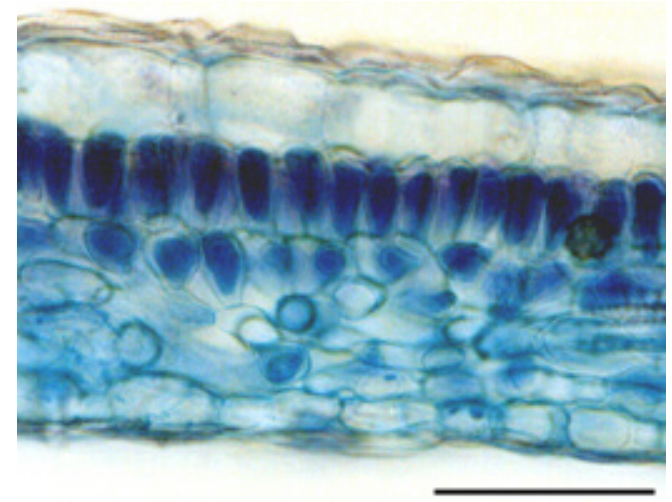

$\mathrm{B}$

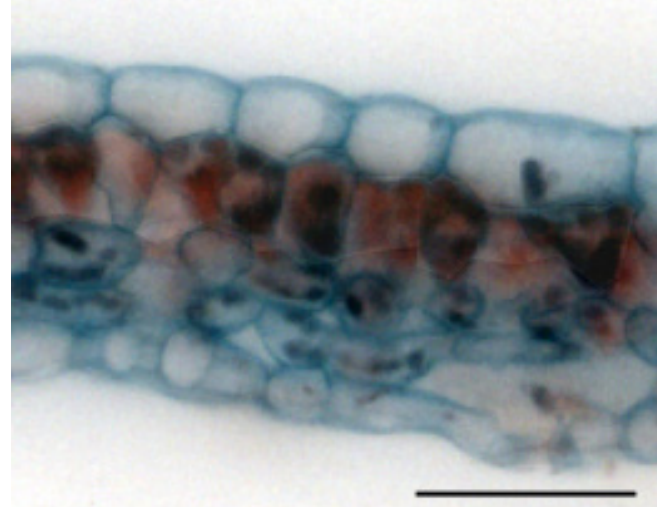

$\mathrm{D}$

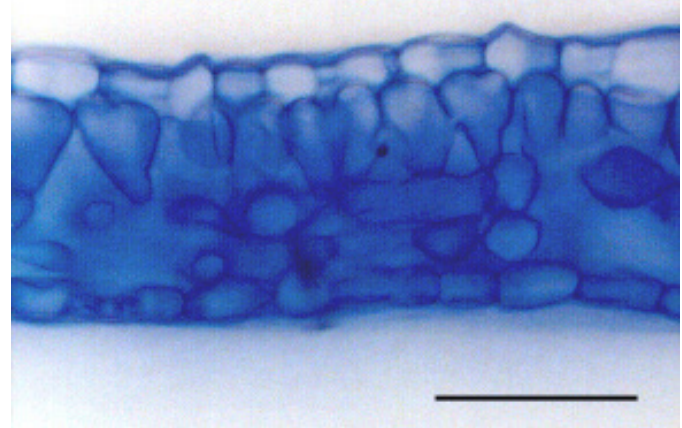

$\mathrm{E}$

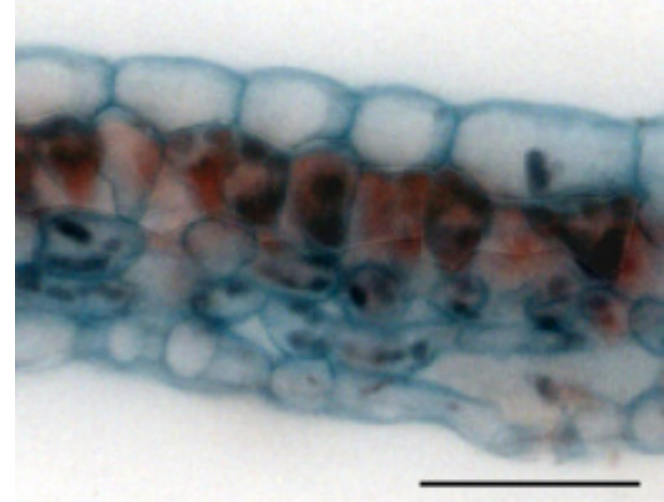

FIGURE 1- Transversal sections of leaves of Ficus carica 'Roxo de Valinhos'; plants in vitro (A), at 20 (B), 40 (C) and 60 (D) days of acclimatization, and field grown (E). Bars correspond to $50 \mu \mathrm{m}$. 
A

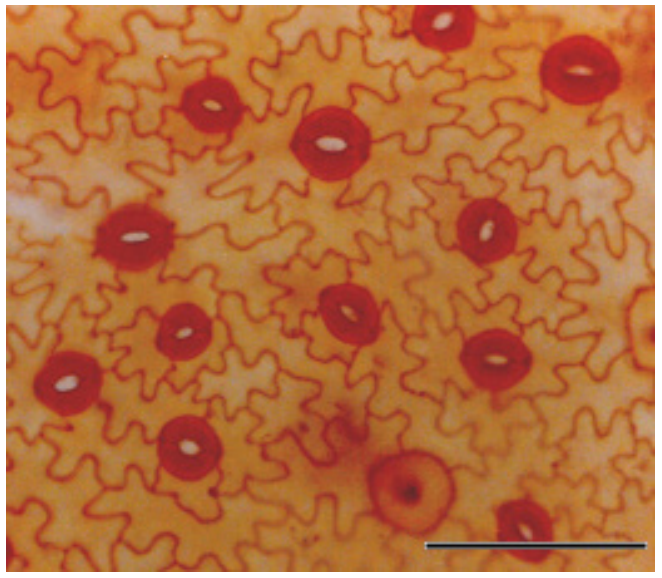

\section{$\mathrm{C}$}

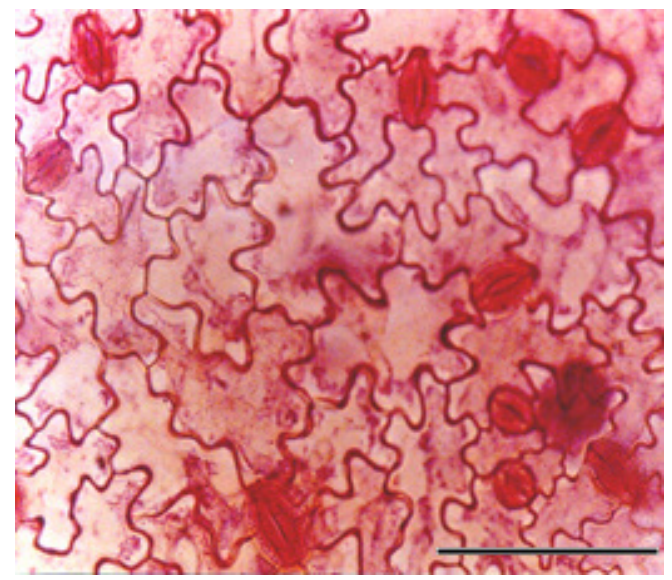

B

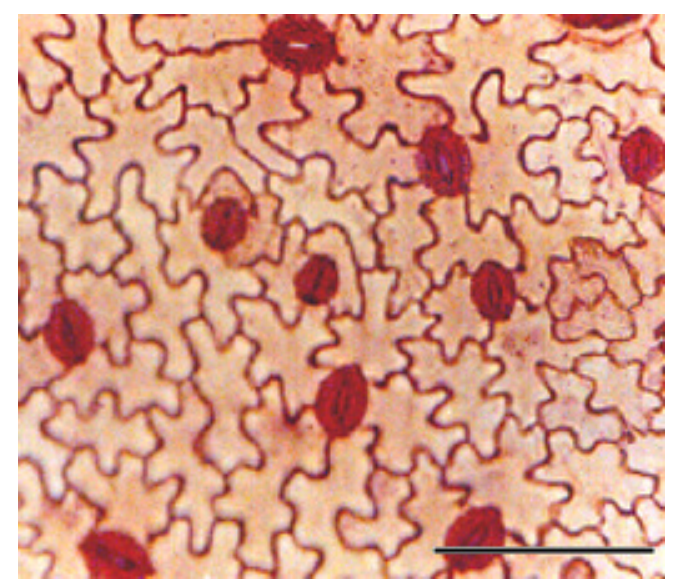

$\mathrm{D}$

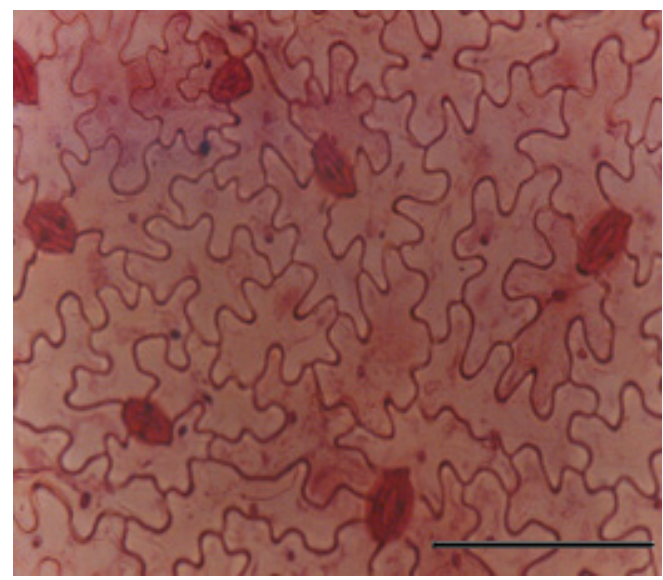

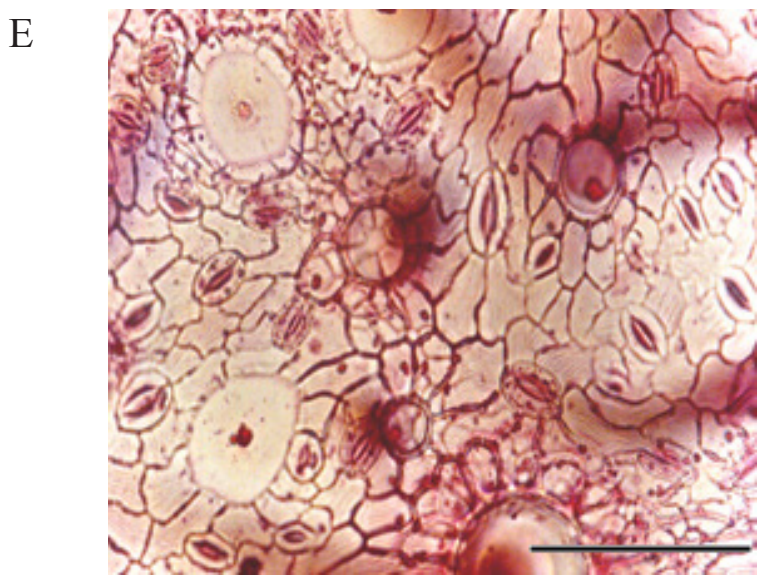

FIGURE 2. Frontal view sections of the abaxial surface epidermis of Ficus carica 'Roxo de Valinhos'; plants in vitro (A), at 20 (B), 40 (C) and 60 (D) days of acclimatization and field grown (E). Bars correspond to $50 \mu \mathrm{m}$. 
TABLE 2 - Mean thickness ( $\mu \mathrm{m}$ ) of epidermal tissues, palisade and spongy parenchyma and leaf blade of naturally grown plants and in vitro developed plantlets after 20, 40 and 60 days of acclimatization.

\begin{tabular}{cccccc}
\hline Treatments & $\begin{array}{c}\text { Adaxial } \\
\text { epidermis }\end{array}$ & $\begin{array}{c}\text { Abaxial } \\
\text { epidermis }\end{array}$ & $\begin{array}{c}\text { Palisade } \\
\text { parenchyma }\end{array}$ & $\begin{array}{c}\text { Spongy } \\
\text { parenchyma }\end{array}$ & Leaf blade \\
\hline In vitro & $15.3 \mathrm{C}$ & $10.0 \mathrm{D}$ & $15,2 \mathrm{D}$ & $21.5 \mathrm{D}$ & $62.1 \mathrm{E}$ \\
20 days & $16.4 \mathrm{C}$ & $10.4 \mathrm{C}$ & $23.6 \mathrm{C}$ & $32.1 \mathrm{C}$ & $82.5 \mathrm{D}$ \\
40 days & $19.8 \mathrm{~B}$ & $10.8 \mathrm{C}$ & $26.9 \mathrm{~B}$ & $32.1 \mathrm{C}$ & $89.6 \mathrm{C}$ \\
60 days & $21.5 \mathrm{~B}$ & $12.0 \mathrm{~B}$ & $28.0 \mathrm{~B}$ & $35.2 \mathrm{~B}$ & $96.7 \mathrm{~B}$ \\
Field & $33.4 \mathrm{~A}$ & $15.1 \mathrm{~A}$ & $99.7 \mathrm{~A}$ & $64.8 \mathrm{~A}$ & $213.0 \mathrm{~A}$ \\
CV (\%) & 6.53 & 3.31 & 2.98 & 5.16 & 2.71 \\
\hline followed by the same letter vertically do not differ by the Scott-Knott test at 5\% of probability.
\end{tabular}

TABLE3 - Stomata density (number of stomata per $\mathrm{mm}^{2}$ of leaf area) and polar (length) and equatorial (width) size $(\mu \mathrm{m})$ of naturally grown plants and in vitro developed plantlets after 20, 40 and 60 days of acclimatization.

\begin{tabular}{cccc}
\hline Treatments & Stomata density & Polar size & Equatorial size \\
\hline In vitro & $206 \mathrm{~B}$ & $22.3 \mathrm{~B}$ & $18.0 \mathrm{~A}$ \\
20 days & $197 \mathrm{~B}$ & $22.8 \mathrm{~B}$ & $18.5 \mathrm{~A}$ \\
40 days & $130 \mathrm{C}$ & $27.4 \mathrm{~A}$ & $18.2 \mathrm{~A}$ \\
60 days & $107 \mathrm{C}$ & $23.2 \mathrm{~B}$ & $14.1 \mathrm{~B}$ \\
Field & $336 \mathrm{~A}$ & $27.5 \mathrm{~A}$ & $18.2 \mathrm{~A}$ \\
CV $(\%)$ & 14.98 & 6.89 & 8.94 \\
\hline
\end{tabular}

Means followed by the same letter vertically do not differ by the Scott-Knott test at $5 \%$ of probability.

\section{CONCLUSIONS}

1. Plantlets cultivated for 30 days in PGRfree WPM presented good development in Plantmax during acclimatization.

2. Field grown plants presented higher number of stomata, greater epicuticular wax thickness and greater leaf tissue production compared to in vitro ones.

3. The leaf tissues of in vitro plantlets show little differentiation and have great stomata number compared with acclimatized plants, which reduce the number of stomata during the acclimatization process.

\section{ACKNOWLEDGMENTS}

This study was supported by Fundação de Amparo à Pesquisa do Estado de Minas Gerais (FAPEMIG), Conselho Nacional de Desenvolvimento Científico e Tecnológico (CNPq) and Coordenação de Aperfeiçoamento de Pessoal de Nível Superior (CAPES).

\section{REFERENCES}

BARRY-ETIENNE, D.; BERTAND, B.; VASQUEZ, N.; ETIENNE, H. Comparison of somatic embryogenesis-derived coffee (Coffea arabica L.) plantlets regenerated in vitro or ex vitro: morphological, mineral and water characteristics. Annals of Botany, London, v.90, p.77-85, 2002.

CASSON, S.; GRAY, J.E. Influence environmental factors on stomatal development. New Phytologist, Cambridge, v.178, p.9-23, 2008.

DEMIRALAY, A.; YALCIN-MENDI, Y.; AKA-KACAR, Y.; CETINER, S.; AKSOY, U.; FERGUSON, L.; HEPAKSOY, S. In vitro propagation of Ficus carica L. var. Bursa Siyahi through meristem culture. Acta Horticulturae, The Hague, v.480, p.165-167, 1998.

DOUSSEAU, S.; ALVARENGA, A.A.; CASTRO, E.M.; SOARES, R.P.; EMRICH, E.B.; MELO, L.A. Leaf anatomy of Tabebuia serratifolia (Vahl) Nich. (Bignoniaceae) propagated in vitro, in vivo and during the acclimatization. Ciência \& Agrotecnologia, Lavras, v.32, p.1694-1700, 2008. 
HANBA, Y.T.; KOGAMI, H.; TERASHIMA, L. The effects of growth irradiance on leaf anatomy and photosynthesis in Acer species differing in light demand. Plant, Cell and Environment, Oxford, v.25, p.1021-1030, 2002.

HAZARIKA, B.N. Acclimatization of tissue-cultured plants. Current Science, Bangalore, v.85, p.17041712, 2003.

KUMAR, V.; RADHA, A.; CHITA, S.K. In vitro plant regeneration of fig (Ficus carica L. cv. Gular) using apical buds from mature trees. Plant Cell Reports, Verlin, v.17, p.717-720, 1998.

LABOURIAU, L.G.; OLIVEIRA, J.G.; SALGADOLABOURIAU, M.L. Transpiração de Schizolobium parahyba (Vell) Toledo I. Comportamento na estação chuvosa, nas condições de Caeté, Minas Gerais. Anais da Academia Brasileira de Ciências, Rio de Janeiro, v.23, p.237-257, 1961.

LAMHAMEDI, M.S,; CHAMBERLAND, H.; TREMBLAY, F.M. Epidermal transpiration, ultrastructural characteristics and net photosynthesis of white spruce somatic seedlings in response to in vitro acclimatization. Physiologia Plantarum, Copenhagen, v.118, p.554-561, 2003.

MURASHIGE, P.; SKOOG, F. A revise medium for rapid growth and bioassays with tobacco tissue cultures. Physiologia Plantarum, Copenhagen, v.15, p.473-479, 1962.
PEREIRA, J.E.S.; FORTES, G.R.L. Multiplicação e aclimatização da macieira influenciada pelo tipo de explante e pelo tempo de permanência em meio de cultura de enraizamento. Revista Brasileira Fruticultura, Jaboticabal, v.23, p.417-420, 2001.

PESCHEL, S.; BEYER, M.; KNOCHE, M. Surface characteristics of sweet cherry fruit: stomata-number, distribution, functionality and surface wetting. Scientia Horticulturae, Amsterdam, v. 97, p. 265 278,2003

POSPÍŠILOVÁ, J.; TICHÁ, I.; KADLEČEK, P.; HAISEL, D.; PSZÁKOVÁ, S. Acclimatization of micropropagated plants to ex vitro conditions. Biologia Plantarum, Praha, v.42, p.481-497, 1999.

RESENDE, R.K.S.; PAIVA, L.V.; PAIVA, R.; CHALFUN, A.; TORGAS, P.P.; CASTRO, E.M. Capitulum organogenesis and anatomical characterization of Gerbera jamesonii Adlan leaves. Ciência \& Agrotecnologia, Lavras, v.32, p.821-827, 2008.

SOUZA, T.C.; MAGALHÃES, P.C.; PEREIRA, F.J.; CASTRO, E.M.; SILVA JÚNIOR, J.M.; PARENTONI, S.N. Leaf plasticity in successive selection cycles of 'Saracura' maize in response to periodic soil flooding. Pesquisa Agropecuária Brasileira, Brasília, v.45, p.16-24, 2010.

YOKOTA, S.; KARIM, M.Z.; AZAD, M.A.K; RAHMAN, M.M.; EIZAWA, J.; SAITO, Y.; YSHIGURI F, IIZUKA K, YAHARA S AND YOSHIZAWAN. Histological observation of changes in leaf structure during successive micropropagation stages in Aralia elata and Phellodendron amurense. Plant Biotechnology, Sheffield, v.24, p.221-226, 2007. 